\title{
PENGARUH PROFITABILITAS, SOLVABILITAS, UKURAN \\ PERUSAHAAN \\ DAN OPINI AUDIT TERHADAP KETEPATAN WAKTU \\ PENYAMPAIAN LAPORAN KEUANGAN
}

\author{
Widdy Kristianto \\ Institut Bisnis dan Informatika Kwik Kian Gie \\ widdykristianto123@gmail.com \\ Prima Apriwenni \\ Institut Bisnis dan Informatika Kwik Kian Gie \\ prima.apriwenni@kwikkiangie.ac.id
}

\begin{abstract}
The purpose of financial reporting is to provide information regarding the financial position, performance, and changes in the financial position of an entity that is beneficial to a large number of users in economic decision-making. Timeliness is an important component that can improve the quality of financial information. Financial information is timely if the information is available to decision-makers before losing capacity to influence decisions.. The purpose of this study is to test whether profitability (ROA), solvency (DER), firm size, and audit opinion affect the timeliness of financial reporting in consumer goods companies listed on Indonesia Stock Exchange in 2013-2016.The object of this research is 24 Consumer Goods companies listed on Indonesia Stock Exchange in 2013-2016. Sampling technique used is Non-Probability Sampling technique, using purposive sampling method. Analytical methods used are descriptive straticistic test, coefficient equality test, classical assumption test, and multiple linear regression analysis.The conclusion of this research indicates that profitability (ROA) has a positive effect on timeliness. solvency (DER) has a negative effect on timeliness. While firm size and audit opinion have no effect on timeliness.
\end{abstract}

Keywords: timeliness, financial reporting, profitability, solvency, firm size, audit opinion

\section{PENDAHULUAN}

Kerangka konseptual pelaporan keuangan menyebutkan bahwa tujuan pelaporan keuangan adalah menyediakan informasi yang menyangkut posisi keuangan, kinerja, serta perubahan posisi keuangan suatu entitas yang bermanfaat bagi sejumlah besar pengguna dalam pengambilan keputusan ekonomi (PSAK 1, 2015). Agar informasi keuangan bermanfaat, maka informasi tersebut harus memenuhi kualitas fundamental informasi akuntansi, salah satu kualitas penting adalah 
relevan. Informasi akuntansi dikatakan relevan jika dapat membuat suatu perbedaan dalam pengambilan keputusan. Ketepatan waktu (timeliness) merupakan komponen penting yang dapat meningkatkan kualitas informasi keuangan. Informasi keuangan dikatakan tepat waktu jika informasi tersebut tersedia bagi para pengambil keputusan sebelum kehilangan kapasitasnya untuk mempengaruhi keputusan (Kieso et al, 2011).

Di Indonesia, pemerintah telah mengatur tentang dasar ketepatan waktu penyampaian laporan keuangan dalam KEP-431/BL/2012, dimana dinyatakan bahwa penyampaian laporan keuangan tahunan kepada BAPEPAM adalah selambat-lambatnya pada akhir bulan keempat atau 120 hari setelah berakhirnya tahun buku.

Dalam Generally Accepted Auditing Standards terdapat standar umum ketiga yang menyatakan bahwa audit harus dilakukan dengan kemahiran profesional yang cermat dan seksama dan standar lapangan ketiga bahwa bukti audit harus cukup dan kompeten. Dengan adanya standarstandar ini memungkinkan akuntan publik untuk memperpanjang masa audit atau menunda waktu publikasi laporan keuangan auditan.

Ketepatan waktu penyampaian laporan keuangan atau yang biasa disebut timeliness erat kaitannya dengan signaling theory yang menyatakan bahwa tindakantindakan yang dilakukan oleh suatu perusahaan merupakan sinyal dari kondisi yang terdapat dalam suatu perusahaan. Jika suatu perusahaan menyampaikan laporan keuangannya secara tepat waktu maka dapat diartikan perusahaan tersebut mempunyai kabar baik (good news) yang informasinya ingin segera disampaikan kepada publik, namun sebaliknya jika perusahaan menyampaikan laporan keuangan tidak tepat waktu, dapat diartikan perusahaan tersebut terdapat kabar buruk (bad news) dimana informasinya sedapat mungkin diperlambat penyampaian kepada publik. Informasi yang terkandung dalam laporan keuangan disebut bermanfaat jika disajikan secara akurat dan tepat waktu, yakni tersedia saat dibutuhkan oleh investor. 
Menurut Penelitian (Mareta, 2015) dan (Toding \& Wirakusuma, 2013) profitabilitas berpengaruh terhadap ketepatan waktu pelaporan keuangan perusahaan. Hal ini berarti bahwa profit yang tinggi merupakan berita baik bagi perusahaan sehingga perusahaan cenderung tidak akan menunda pelaporan informasi keuangannya. Hasil Penelitian tersebut berbeda dengan hasil penelitian yang dilakukan oleh (Kadir, 2011) dan (Rachmawati, 2008). Pada penelitian ini memiliki hasil bahwa tingkat profitabilitas tidak berpengaruh terhadap ketepatan waktu penyampaian laporan keuangan perusahaan. Ketepatan waktu perusahaan untuk menyerahkan laporan keuangan tidak dipengaruhi oleh tinggi rendahnya profitabilitas suatu perusahaan.

Pada penelitian (S. P. Dewi \& Jusia, 2013) dan (Merdekawati \& Arsjah, 2011), debt to equity ratio mempunyai pengaruh terhadap ketepatan waktu penyampaian laporan keuangan perusahaan. Pihak manajemen cenderung menunda penyampaian laporan keuangannya karena adanya risiko keuangan yang tinggi. Penundaan ini bisa disebabkan karena pihak manajemen akan menghapus informasi tersebut dalam neraca untuk menekan debt to equity ratio serendah mungkin. Tetapi hasil penelitian tersebut berbeda dengan penelitian yang dilakukan oleh (Wiratmo, 2013) dan (Yusralaini, Agusti, \& Raesya, 2010), yang menyatakan bahwa debt to equity ratio tidak memiliki pengaruh terhadap ketepatan waktu pelaporan keuangan (timeliness). Debt to equity ratio (DER) yang tinggi mencerminkan tingginya resiko keuangan perusahaan, ini memungkinkan bahwa perusahaan tersebut tidak bisa melunasi kewajiban atau hutangnya baik berupa pokok maupun bunganya.

Hasil penelitian (Toding \& Wirakusuma, 2013) dan (Merdekawati \& Arsjah, 2011), menyatakan bahwa ukuran perusahaan berpengaruh positif pada ketepatan waktu penyampaian laporan keuangan diterima. (S. P. Dewi \& Jusia, 2013) dan (Hilmi \& Ali, 2008) yang menyatakan bahwa ukuran perusahaan tidak berpengaruh terhadap ketepatan waktu penyampaian pelaporan keuangan. Karena walaupun aset perusahaan 
kecil tapi item-item yang dimiliki lebih banyak dibandingkan dengan perusahaan besar.

Berdasarkan penelitian (Mareta, 2015) dan (Merdekawati \& Arsjah, 2011) menyatakan opini audit berpengaruh terhadap ketepatan waktu pelaporan keuangan perusahaan di Bursa Efek Indonesia. Sedangkan penelitian (S. P. Dewi \& Jusia, 2013) menunjukkan bahwa opini audit tidak mempunyai pengaruh terhadap ketepatan waktu penyampaian laporan keuangan perusahaan. Hasil penelitian ini menunjukkan bahwa opini audit suatu perusahaaan tidak mempengaruhi ketepatan waktu penyampaian laporan keuangan perusahaan.

Rumusan masalah yang akan dibahas dalam penelitian ini adalah apakah profitabilitas, solvabilitas, ukuran perusahaan, dan opini audit mempengaruhi ketepatan waktu penyampaian laporan keuangan pada perusahaan consumer goods periode yang terdaftar di BEI 2013-2016.

Tujuan dari penelitian ini adalah untuk mengetahui apakah profitabilitas, solvabilitas, ukuran perusahaan, dan opini audit mempengaruhi ketepatan waktu penyampaian laporan keuangan. Penelitian ini diharapkan dapat menambah pandangan dan wawasan yang lebih dalam auditing.

\section{TELAAH LITERATUR}

\section{Teori Keagenan}

Jensen \& Meckling, (1976) menyatakan bahwa hubungan keagenan merupakan suatu kontrak dimana salah satu atau lebih pemegang saham (principal) memerintahkan manajer (agent) untuk melakukan suatu jasa atas nama principal serta memberikan wewenang kepada agent untuk membuat keputusan yang terbaik bagi principal. Akan tetapi dalam pelaksanaannya, manajer tidak selalu bertindak berdasarkan kepentingan principal.

Menurut Scott (2015:358), teori agensi merupakan cabang dari game theory yang mempelajari hubungan yang dapat memotivasi agent secara rasional untuk dapat berperan atas nama principal ketika kepentingan agent tersebut tidak bertentangan dengan kepentingan dari principal. Oktomegah, (2012) menjelaskan bahwa teori agensi adalah hubungan 
agensi yang muncul ketika satu orang atau lebih pemilik (principal) mempekerjakan orang lain (agent) untuk memberikan suatu jasa dan kemudian memberikan wewenang untuk mengambil keputusan kepada agent tersebut.

Teori agensi menekankan pentingnya pemegang saham (principal) menyerahkan pengelolaan perusahaan kepada tenaga-tenaga professional yang disebut agent yang lebih mengerti dalam menjalankan bisnis sehari-hari. Pemegang saham dan manajer memiliki tujuan yang berbeda dan masing-masing menginginkan tujuan mereka terpenuhi. Akibat yang terjadi adalah munculnya konflik kepentingan. Pemegang saham menginginkan pengembalian yang lebih besar dan lebih cepat atas investasi yang mereka tanamkan sedangkan manajer menginginkan kepentingannya diakomodasi dengan pemberian insentif yang besar atas kinerjanya dalam menjalankan perusahaan. Kondisi perusahaan yang dilaporkan oleh manajer tidak sesuai atau tidak mencerminkan keadaan perusahaan yang sesungguhnya. Hal ini disebabkan adanya perbedaan informasi yang dimiliki antara manajer dengan pemegang saham.

\section{Teori Signalling}

Sinyal adalah sebuah tindakan yang lebih sering diambil oleh manajer tingkat atas dibandingkan dengan manajer tingkat bawah. Salah satu hal penting dari sebuah sinyal dilihat dari segi biayanya yang murah dan lebih berdampak pada manajer tingkat atas dibandingkan manajer tingkat bawah. Hal tersebut yang menunjukkan tingkat kredibilitas dari sebuah sinyal (Scott, 2015: 503).

Menurut Wolk (2001: 101), teori sinyal menjelaskan mengapa perusahaan memiliki insentif untuk melaporkan secara sukarela kepada pasar modal meskipun tidak ada persyaratan pelaporan wajib. Perusahaan saling bersaing satu sama lain untuk modal risiko yang langka dan pengungkapan sukarela diperlukan agar dapat bersaing dengan sukses di pasar untuk modal risiko tersebut. Insentif ekonomi untuk melaporkan (bahkan berita buruk) merupakan inti dari argumen teori sinyal untuk pelaporan keuangan sukarela. Ada informasi asimetris antara pihak dalam dan 
pihak luar karena pihak dalam lebih mengetahui tentang perusahaan dan prospek masa depannya dibandingkan pihak luar (investor). Bagaimanapun juga, nilai perusahaan dapat meningkat jika perusahaan melakukan pelaporan sukarela (sinyal) mengenai informasi perusahaan yang kredibel dan dapat mengurangi keraguan pihak luar terhadap prospek masa depan perusahaan.

Menurut (Jaswadi, 2004), upaya manajer untuk meningkatkan kemakmuran pemegang saham adalah dengan mengkomunikasikan good news kepada pasar untuk meningkatkan harga saham. Untuk mentransfer news, manajer dapat men-disclose secara langsung. Namun, pengungkapan eksplisit mungkin berbahaya pada perusahaan dengan alasan kompetitif atau larangan dari klausal perjanjian kerahasiaan perusahaan. Ketika pengungkapan langsung tidak mungkin dilakukan, manajer dapat mengungkapkan sinyal tertentu bahwa harga saham underpriced.

Signalling Theory mengemukakan tentang bagaimana seharusnya sebuah perusahaan memberikan sinyal kepada pengguna laporan keuangan. Sinyal ini berupa informasi mengenai apa yang sudah dilakukan oleh manajemen untuk merealisasikan keinginan pemilik. Sinyal dapat berupa promosi atau informasi lain yang menyatakan bahwa perusahaan tersebut lebih baik daripada perusahaan lain.

\section{Timeliness}

Timeliness atau ketepatan waktu penyampaian laporan keuangan menurut Kieso et al. (2011:47), "Ketepatan waktu berarti memiliki informasi yang tersedia kepada pengambil keputusan sebelum kehilangan kapasitasnya untuk mempengaruhi keputusan. Memiliki informasi yang relevan tersedia cepat dapat menambah kapasitasnya untuk mempengaruhi keputusan, dan kurangnya ketepatan waktu dapat mengurangi informasi kegunaannya."

Menurut Chambers dan Penman (1984: 21), ketepatan waktu dapat didefinisikan dengan dua cara, yaitu:

a) Ketepatan waktu dilihat dari apakah adanya reporting lag dari tanggal laporan keuangan sampai tanggal melaporkan, dan 
b) Ketepatan waktu ditentukan dengan ketepatan waktu pelaporan relatif atas tanggal pelaporan yang diharapkan.

Menurut Dyer \& McHugh, (1975) menggunakan tiga kriteria keterlambatan untuk melihat ketepatan waktu dalam penelitiannya:

a) preliminary lag: interval jumlah hari antara tanggal laporan keuangan sampai penerimaan laporan akhir (preliminary) oleh bursa.

b) auditor's report lag: interval jumlah hari antara tanggal laporan keuangan sampai tanggal laporan auditor ditandatangani.

c) total lag: interval jumlah hari antara tanggal laporan keuangan sampai tanggal penerimaan laporan dipublikasikan oleh bursa.

\section{Profitabilitas}

Menurut Asnawi dan Wijaya (2015:26), rasio profitabilitas/ laba menunjukkan kemampuan perusahaan mendapatkan hasil (keuntungan/ kerugian) selama satu periode produksi. Perusahaan akan cenderung untuk memberikan informasi tersebut pada pihak lain yang berkepentingan dengan segera sehingga dapat dikatakan bahwa profit merupakan berita baik (good news) bagi perusahaan. Perusahaan yang memiliki berita baik tersebut tidak akan menunda penyampaian informasi.

Menurut Sugiono (2009:80), ROA merupakan rasio profitabilitas yang mengukur tingkat pengembalian dari bisnis atas seluruh aset yang ada. Apabila ROA memiliki nilai yang tinggi, maka kinerja perusahaan dalam mengelola asset menjadi laba bagi perusahaan sangat baik. Kemampuan perusahaan ini akan dilihat oleh investor, makin baik kemampuan perusahaan tersebut maka semakin tertarik investor untuk menanamkan modal di perusahaan tersebut, (Diaz dan Jufrizen, 2014).

$\mathrm{H}_{1:}$ Profitabilitas (ROA) berpengaruh negatif terhadap timeliness.

\section{Solvabilitas}

Menurut (Rachmawati, 2008), leverage atau solvabilitas berpengaruh signifikan terhadap ketapatan waktu dalam publikasi 
laporan keuangan (timeliness). Jika proporsi yang besar dari hutang terhadap total aktiva akan meningkatkan kecenderungan kerugian dimana semakin tinggi proporsi hutang maka akan semakin tinggi pula risiko kerugiannya. Dengan terjadinya hal tersebut maka auditor perlu meningkatkan kehatihatian dalam mengaudit laporan keuangan perusahaan tersebut.

Tingkat solvabilitas dapat diukur melalui rasio-rasio solvabilitas atau leverage. Menurut Kasmir (2015:113) solvabilitas merupakan rasio yang digunakan untuk mengukur sejauh mana aktiva perusahaan dibiayai dengan hutang. Artinya besarnya jumlah hutang yang digunakan perusahaan untuk membiayai kegiatan usahannya jika dibandingkan dengan menggunakan modal sendiri. Dalam arti luas dikatakan bahwa rasio solvabilitas digunakan untuk mengukur kemampuan perusahaan untuk membayar seluruh kewajibannya, baik jangka pendek maupun jangka panjang apabila perusahaan dibubarkan (dilikuidasi).
$\mathrm{H}_{2:}$ Solvabilitas (DER) berpengaruh positif terhadap timeliness.

\section{Ukuran Perusahaan}

Menurut (Sudarmadji \& Sularto, 2007), total aset dipilih sebagai proksi dari variabel ukuran perusahaan karena total aset lebih stabil dan representatif dalam menunjukkan ukuran perusahaan dibandingkan dengan kapitalisasi pasar dan penjualan yang sangat dipengaruhi oleh permintaan dan penawaran. Suatu perusahaan yang mempunyai aset besar akan memiliki banyak sumber informasi, sumberdaya manusia dan sistem informasi yang canggih sehingga memungkinkan perusahaan tersebut melaporkan laporan keuangan secara cepat ke publik.

Menurut (Dewi \& Wirakusuma, 2014) ukuran perusahaan yang besar, lebih banyak memiliki staf sehingga pembuatan dan penyusunan laporan keuangannya lebih cepat, otomatis penyampaian laporan keuangannya juga tepat waktu. Selain itu ukuran perusahaan dapat menunjukkan seberapa besar informasi yang terdapat didalamnya, sekaligus mencerminkan kesadaran dari pihak 
manajemen mengenai pentingnya informasi.

$\mathrm{H}_{3:}$ Ukuran Perusahaan berpengaruh positif terhadap timeliness.

\section{Opini Audit}

Jenis opini audit menurut Standar Profesional Akuntan Publik (SPAP 29 SA Seksi 508), ada lima jenis pendapat akuntan yaitu: a.) Pendapat wajar tanpa pengecualian (unqualified opinion), b.)Pendapat wajar tanpa pengecualian dengan bahasa penjelasan yang ditambahkan dalam laporan audit bentuk baku (unqualified opinion with explanatory language), c.) Pendapat wajar dengan pengecualian (qualified opinion), d.) Pendapat tidak wajar (adverse opinion), e.) Pernyataan

\author{
tidak memberikan pendapat \\ (disclaimer opinion).
}

$\mathrm{H}_{4}$ : Opini Audit berpengaruh negatif terhadap timeliness.

\section{METODOLOGI PENELITIAN}

Penelitian ini menggunakan data dari laporan keuangan auditan tahun 2013-2016, untuk perusahaan consumer goods yang terdaftar di Bursa Efek Indonesia (BEI). Penelitian ini menggunakan sampel sebanyak 24 perusahaan consumer goods yang terdaftar di Bursa Efek Indonesia per tahunnya, sehingga total sampel menjadi 96 perusahaan dengan mempertimbangkan kelengkapan dan data laporan tahunan masing-masing emiten.

Tabel 1. Proses Pengambilan Sampel

\begin{tabular}{clc}
\hline No. & \multicolumn{1}{c}{ Keterangan } & JumlahPerusahaan \\
\hline 1. & $\begin{array}{l}\text { Perusahaan consumer goods yang terdaftar } \\
\text { di BEI selama tahun 2013-2016 }\end{array}$ & 37 \\
2. & $\begin{array}{l}\text { Perusahaan tidak memiliki kelengkapan } \\
\text { data selama tahun 2013-2016 }\end{array}$ & $(10)$ \\
3. & $\begin{array}{l}\text { Perusahaan yang delisting selama } \\
\text { pengujian }\end{array}$ & $(0)$ \\
4. & Perusahaan yang baru listing \\
5. & $\begin{array}{l}\text { Perusahaan yang tidak menyajikan laporan } \\
\text { keuangan dalam mata uang Rupiah } \\
\text { Total perusahaan }\end{array}$ & $(0)$ \\
\hline
\end{tabular}


Definisi Operasional Variabel dan Pengukuran Variabel Penelitian

\section{Variabel Dependen}

Variabel dependen dalam penelitian ini adalah ketepatan waktu (timeliness). Variabel ini bersifat kuantitatif yang diukur berdasarkan jumlah hari dari tanggal tutup buku perusahaan (31 Desember) sampai tanggal dipublikasikan laporan keuangan tahunan.

\section{Variabel Independen}

Variabel bebas di dalam penelitian ini terdiri dari :

\section{a. Profitabilitas}

Tingkat Profitabilitas menunjukkan gambaran kemampuan suatu perusahaan dalam menghasilkan keuntungan atau laba dari kegiatan operasinya.

Adapun rumus untuk menghitung Return on Asset (ROA) sebagai berikut

Return on Asset $($ ROA $)=$ $\frac{\text { Net Income }}{\text { Total Assets }}$

\section{b. Solvabilitas}

Solvabilitas berarti kemampuan suatu perusahaan untuk membayar seluruh hutangnya, baik jangka pendek maupun jangka panjang.
Dalam penelitian ini menggunakan rasio Debt to Equity Ratio (DER).

Adapun rumus untuk menghitung Debt to Equity Ratio (DER) sebagai berikut

Debt to Equity Ratio (DER) = $\frac{\text { Total Debt }}{\text { Total Equity }}$

\section{c. Ukuran Perusahaan}

Ukuran perusahaan adalah suatu skala yang mengklasifikasikan besar kecilnya perusahaan dan meunujukkan kekayaan yang dimiliki oleh perusahaan. Ukuran perusahaan diukur dengan logaritma natural total aset.

Adapun rumus untuk menghitung Ukuran Perusahaan sebagai berikut :

\section{$\mathrm{SIZE}=\ln$ total asset}

\section{d. Opini Audit}

Opini Audit merupakan dummy variable. Variabel ini terdiri dari 2 kategori yaitu kode "1" untuk opini unqualified dan kode "0" untuk opini selain unqualified. Pemberian nilai ini didasarkan pada asumsi bahwa perusahaan yang mendapatkan opini lebih baik (unqualified) akan sesegera mungkin menyampaikan laporan keuangan ke Bapepam. 


\section{Teknik Pengambilan Sampel}

Dalam penelitian ini populasi yang digunakan merupakan seluruh perusahaan barang yang dikonsumsi (consumer goods) periode 20132016. Dari populasi yang ada ini, peneliti mengambil sampel dengan menggunakan teknik non probability sampling, yaitu metode purposive sampling. Dengan teknik non probability sampling ini, tidak semua elemen populasi memiliki peluang/ kesempatan sama untuk dipilih menjadi sampel, dimana ada bagian tertentu yang secara disengaja tidak dijadikan sampel. Dalam penelitian ini, penulis menggunakan metode purposive sampling, yaitu pengambilan sampel yang didasarkan pada pertimbangan penulis diharapkan dapat memberikan kontribusi dalam masalah penelitian. Sampel yang digunakan oleh peneliti merupakan sampel yang dapat mewakili populasi dengan kriteriakriteria sebagai berikut :

1. Perusahaan consumer goods yang terdaftar di Bursa Efek Indonesia periode 2013-2016.

2. Perusahaan menerbitkan laporan keuangan auditan dengan tanggal tutup buku 31 Desember periode 2013-2016.

3. Perusahaan consumer goods yang memiliki kelengkapan data yang diperlukan dalam penelitian mengenai Return on Asset (ROA), Debt to Equity Ratio (DER), ukuran perusahaan, opini audit.

4. Perusahaan tidak di-delisting selama periode penelitian.

5. Mata uang dalam laporan keuangan auditan perusahaan harus dalam rupiah.

\section{Teknik Analisis Data}

Teknik analisis data yang digunakan dalam penelitian ini antara lain :

\section{Analisis Statistik Deskriptif}

Ghozali (2016: 19) menyatakan statistik deskriptif digunakan untuk memberikan gambaran atau deskripsi suatu data yang dilihat dari nilai ratarata (mean), standar deviasi, varian, maksimum, minimum, sum, range, kurtosis dan skewness (kemencengan distribusi).

Penelitian ini menggunakan alat ukur nilai rata-rata (mean), maksimum, dan minimum. Mean digunakan untuk memperkirakan besar rata-rata populasi yang diperkirakan dari sampel. Maksimum-minimum 
digunakan untuk melihat gambaran keseluruhan dari sampel yang berhasil dikumpulkan dan memenuhi syarat untuk disajikan sampel penelitian.

\section{Uji Kesamaan Koefisien}

Sebelum melakukan pengujian atas pengaruh variabel-variabel independen terhadap variabel dependen. Sebelumnya perlu diketahui apakah pooling data penelitian (penggabungan data crosssectional dan time series) dapat dilakukan atau tidak. Untuk itu perlu dilakukan suatu pengujian yaitu pengujian comparing two regression: the dummy variable approach.

\section{Uji Asumsi Klasik}

Uji Multikolinearitas

Menurut Imam Ghozali (2016 :103), uji multikolinearitas bertujuan untuk menguji apakah model regresi ditemukan adanya korelasi antara variabel bebas (independen). Pengujian multikolinearitas dapat dilihat dari besaran VIF dan tolerance.

Dasar pengambilan keputusan adalah
(1) Jika nilai VIF $<10$ dan nilai tolerance $>0,1$, maka model tidak terjadi multikolinearitas.

(2) Jika nilai VIF > 10 dan nilai tolerance $<0,1$, maka model terjadi multikolinearitas.

Uji Autokorelasi

Untuk menguji apakah dalam model regresi tersebut terjadi autokorelasi atau tidak, diperlukan uji autokorelasi yang bertujuan menguji apakah dalam suatu model regresi linear ada korelasi antara kesalahan pengganggu pada periode $t$ dengan kesalahan pada periode $\mathrm{t}-1$ (sebelumnya). Salah satu cara untuk mengetahui ada tidaknya autokorelasi pada model regresi adalah dengan melakukan uji Durbin Watson (Ghozali, 2016 : 107)

Pengambilan keputusan ada tidaknya korelasi :

(1) Bila nilai dw terletak antara batas atas atau upper bound (du) dan (4-du), maka koefisien autokorelasi sama dengan nol, berarti tidak ada autokorelasi. 
(2) Bila nilai dw lebih rendah daripada batas bawah atau lower bound (dl), maka koefisien autokorelasi lebih besar daripada nol, berarti ada autokorelasi positif.

(3) Bila nilai dw lebih besar daripada (4-dl), maka koefisien autokorelasi lebih kecil daripada nol, berarti ada autokorelasi negatif.

(4) Bila nilai dw negatif diantara batas atas atau upper bound (du) dan batas bawah atau lower bound (dl) atau $\mathrm{dw}$ terletak antara (4-du) dan (4dl), maka hasilnya tidak dapat disimpulkan.

\section{Uji Heteroskedastisitas}

Menurut Imam Ghozali (2016:134), uji heteroskedastisitas bertujuan menguji apakah model regresi terjadi ketidaksamaan varians dari residual satu pengamatan ke pengamatan lain. Heteroskedastisitas dapat dideteksi dengan beberapa cara, dalam penelitian ini menggunakan uji Glejser.

Dasar pengambilan keputusan adalah
(1)Jika Sig. $\geq \alpha(0,05)$ maka tidak terjadi heteroskedastisitas.

(2)Jika Sig. < $\alpha(0,05)$, makaterjadi heteroskedasitisitas.

\section{Uji Normalitas}

Uji statistik yang digunakan untuk menguji normalitas adalah uji statistik non parametric one sample kolmogorov smirnov test. Jika angka probabilitas $<\alpha=0,05$ maka variabel tidak terdistribusi secara normal. Sebaliknya,bila angka probabilitas > $\alpha=0,05$ maka variabel terdistribusi secara normal (Ghozali, 2016 : 154).

\section{Analisis Regresi Linear Berganda}

Dalam penelitian ini pengujian dilakukan dengan analisis regresi linier berganda, analisis ini merupakan suatu metode statistik yang digunakan untuk meneliti hubungan antara sebuah variabel dependen dengan beberapa variabel independen. Model analisis yang digunakan adalah sebagai berikut :

$\mathrm{TIME}=\beta 0+\beta 1 \mathrm{ROA}+\beta 2 \mathrm{DER}+\beta 3 \mathrm{UP}+\beta 4 \mathrm{OPINI}+\varepsilon$ 


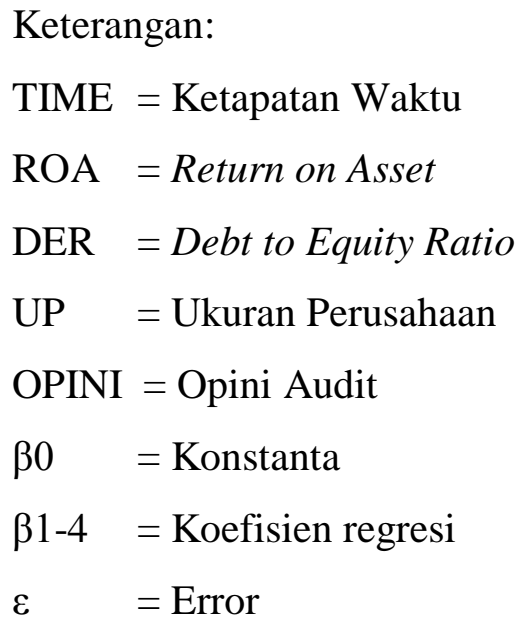

\section{Pengujian Hipotesis}

a. Uji statistik F (Uji Signifikansi Simultan)

Menurut Imam Ghozali

(2016:99), pengujian ini dilakukan untuk menguji apakah semua variabel independen secara bersamasama mempunyai pengaruh terhadap variabel dependen.

Dasar Pengambilan keputusan adalah :

(1) Jika sig-F $<\alpha(0,05)$, berarti model regresi signifikan, artinya secara bersama-sama semua variabel independen berpengaruh terhadap variabel dependen.

(2) Jika sig-F $\geq \alpha(0,05)$, berarti model regresi tidak signifikan, artinya secara bersama-sama semua variabel independen tidak berpengaruh terhadap variabel dependen.

b. Uji Statistik t (Uji Signifikansi Parameter Individual)

Menurut Imam Ghozali (2016: 99), pengujian ini digunakan untuk mengetahui apakah variabel independen secara individual berpengaruh terhadap variabel dependen.

Dasar Pengambilan keputusan :

(1) Jika nilai sig > a $(0,05)$ maka variabel independen tidak berpengaruh signifikan terhadap variabel dependen. 
(2) Jika nilai sig $\leq$ a $(0,05)$ maka variabel independen berpengaruh signifikan terhadap variabel dependen.

c. Koefisien determinasi $\left(\mathrm{R}^{2}\right)$

Menurut Imam Ghozali (2016: 98), koefisien determinasi $\left(\mathrm{R}^{2}\right)$ dilakukan untuk mengukur seberapa jauh kemampuan model dalam menerangkan variasi variabel dependen. Koefisien determinasi $\left(\mathrm{R}^{2}\right)$ adalah bagian dari keragaman total variabel dependen yang dapat diterangkan atau diperlihatkan oleh keragaman variabel independen. Batasnya adalah $0 \leq \mathrm{R}^{2} \leq 1$, dimana :

(1) Jika R2 = 0, artinya model regresi tidak menjelaskan sedikitpun variasi dalam $\mathrm{Y}$.

(2) Jika R2 = 1, artinya model regresi yang terbentuk dapat meramalkan variabel dependen secara sempurna. Kecocokan model dikatakan "lebih baik" kalau R2 semakin dekat dengan 1.

\section{HASIL \& ANALISIS}

Tabel 2. Descriptive Statistic Result

\begin{tabular}{lrrrrr}
\hline Parameter & $\mathrm{N}$ & Minimum & Maximum & Mean & $\begin{array}{c}\text { Std. } \\
\text { Deviation }\end{array}$ \\
\hline Time & 96 & 66 & 124 & 94.30 & 12.623 \\
Roa & 96 & -.0971 & .3948 & .100236 & .0962080 \\
Der & 96 & .1636 & 1.7190 & .728181 & .4279870 \\
Up & 96 & 25.2954 & 32.1510 & 28.5177 & 1.7243050 \\
Opini & 96 & 0 & 1 & .77 & .423 \\
Valid N & 96 & & & & \\
(listwise) & & & & & \\
\hline
\end{tabular}

\section{Analisis Statistik Deskriptif}

Berdasarkan tabel 2, dapat dilihat bahwa variabel ketepatan waktu memiliki rata-rata sebesar 94,30 (95 hari), di mana laporan keuangan di BEI paling cepat dapat dilakukan oleh INAF dan MERK dalam waktu 66 hari dan yang paling lama 
dilakukan oleh AISA dalam waktu 124 hari.

Variabel ROA memiliki nilai ratarata sebesar 0,100236 dengan nilai tertinggi 0,3948 yang dimiliki oleh HMSP dan nilai terendah dimiliki oleh KICI sebesar -0,0971.

Variabel DER memiliki rata-rata sebesar 0,728181 dengan nilai tertinggi 1,7190 yang dimiliki oleh
SKBM dan nilai terendah 0,1636 yang dimiliki oleh MRAT.

Variabel Ukuran Perusahaan memiliki rata-rata sebesar 28,517798 dengan nilai tertinggi 32,1510 yang dimiliki oleh INDF dan nilai terendah sebesar 25,2954 yang dimiliki oleh KICI.

Variabel Opini Audit memiliki ratarata sebesar 0,77 dengan nilai tertinggi 1 dan nilai terendah 0 .

\section{Uji Kesamaan Koefisien}

Tabel 3. Hasil Uji Kesamaan Koefisien

\begin{tabular}{lrrrrr}
\hline Model & \multicolumn{2}{c}{ Unstandardized Coefficients } & Standardized Coefficients & $\mathrm{t}$ & Sig. \\
& \multicolumn{1}{c}{ B } & Std. Error & Beta & & \\
\hline (Constant) & 105.974 & 33.233 & & 3.189 & .002 \\
Roa & -8.852 & 26.307 & -.067 & -.336 & .737 \\
Der & -.467 & 5.504 & -.016 & -.085 & .933 \\
Up & .000 & 1.188 & .000 & .000 & 1.000 \\
Opini & -1.898 & 6.176 & -.064 & -.307 & .759 \\
dt1 & -48.038 & 46.886 & -1.656 & -1.025 & .309 \\
dt2 & -29.803 & 47.157 & -1.028 & -.632 & .529 \\
dt3 & -67.355 & 48.956 & -2.323 & -1.376 & .173 \\
dt1_roa & -37.557 & 35.121 & -.189 & -1.069 & .288 \\
dt1_der & -12.246 & 7.519 & -.384 & -1.629 & .107 \\
dt1_up & 1.898 & 1.700 & 1.875 & 1.117 & .268 \\
dt1_opini & 7.583 & 7.677 & .219 & .988 & .326 \\
dt2_roa & -17.130 & 33.874 & -.088 & -.506 & .615 \\
dt2_der & .875 & 7.522 & .026 & .116 & .908 \\
dt2_up & .296 & 1.739 & .291 & .170 & .865 \\
dt2_opini & 5.967 & 7.963 & .189 & .749 & .456 \\
dt3_roa & -20.335 & 33.169 & -.112 & -.613 & .542 \\
dt3_der & -2.850 & 7.132 & -.090 & -.400 & .691 \\
dt3_up & 1.612 & 1.717 & 1.581 & .939 & .351 \\
dt3_opini & 11.975 & 8.073 & .380 & 1.483 & .142 \\
\hline a. Dependent Vara & & & & &
\end{tabular}

a. Dependent Variable: time 


\section{Uji kesamaan Koefisien}

Dari hasil uji pooling ini ditemukan bahwa semua variabel dummy yang digunakan dalam penelitian ini dapat di-pool, karena semua variabel

\section{Uji Normalitas}

Tabel 4. One-Sample Kolmogorov-Smirnov Test

\begin{tabular}{|c|c|c|}
\hline Parameter & & Unstandardized Residual \\
\hline $\mathrm{N}$ & & 96 \\
\hline \multirow{3}{*}{ Normal Parameters ${ }^{\mathrm{a}, \mathrm{b}}$} & Mean & $0 \mathrm{E}-7$ \\
\hline & Std. Deviation & 11.98695189 \\
\hline & Absolute & .063 \\
\hline \multirow[t]{2}{*}{ Most Extreme Differences } & Positive & .063 \\
\hline & Negative & -.033 \\
\hline Kolmogorov-Smirnov Z & & .618 \\
\hline Asymp. Sig. (2-tailed) & & .839 \\
\hline
\end{tabular}

\section{Uji Normalitas}

Dari hasil pengujian normalitas didapatkan nilai Asymp.Sig (2tailed) sebesar 0,839, nilai tersebut dummy memiliki hasil signifikansi melebihi 0,05. (Lihat tabel 3 Hasil Uji Kesamaan Koefisien). Oleh karena itu, maka dapat dilakukan uji lebih lanjut, yaitu uji asumsi klasik.

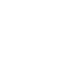

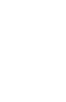

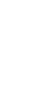

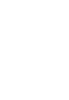


Uji Heteroskedastisitas

Dari pengujian heteroskedastisitas yang telah dilakukan menunjukkan bahwa nilai Signifikansi > $>0,05$

\section{Uji Autokorelasi}

Tabel 6. Hasil Uji Autokorelasi (Durbin Watson)

\begin{tabular}{lrrrrr}
\hline Model & R & R Square & $\begin{array}{c}\text { Adjusted R } \\
\text { Square }\end{array}$ & $\begin{array}{l}\text { Std. Error of } \\
\text { the Estimate }\end{array}$ & $\begin{array}{l}\text { Durbin- } \\
\text { Watson }\end{array}$ \\
\hline 1 & $.371^{\mathrm{a}}$ & .138 & .089 & 11.36164502 & 2.148
\end{tabular}

a. Predictors: (Constant), lagres, der, up, opini, roa

b. Dependent Variable: Unstandardized Residual

\section{Uji Autokorelasi}

Berdasarkan uji autokorelasi yang menggunakan Durbin - Watson Test. Nilai Durbin - Watson sebesar 2,148 dan berdasarkan tabel DurbinWatson dengan $\alpha=5 \%$, nilai $\mathrm{dU}$ sebesar 1,7553. Dari hal tersebut, dapat disimpulkan penelitian ini lolos uji autokorelasi karena nilai 2,148 berada diantara nilai 1.7553 dan 2.2447 ( 4 - 1.7553). (Lihat tabel 6 Uji Autokorelasi).

\section{Uji Multikolinearitas}

\section{Tabel 7. Hasil Uji Multikolinearitas}

\begin{tabular}{|c|c|c|c|c|c|c|c|}
\hline \multirow[t]{2}{*}{ Model } & \multicolumn{2}{|c|}{$\begin{array}{c}\text { Unstandardized } \\
\text { Coefficients }\end{array}$} & \multirow{2}{*}{$\begin{array}{c}\text { Standardized } \\
\text { Coefficients } \\
\text { Beta }\end{array}$} & \multirow[t]{2}{*}{$\mathrm{t}$} & \multirow[t]{2}{*}{ Sig. } & \multicolumn{2}{|c|}{$\begin{array}{c}\text { Collinearity } \\
\text { Statistics }\end{array}$} \\
\hline & B & $\begin{array}{l}\text { Std. } \\
\text { Error }\end{array}$ & & & & Tolerance & VIF \\
\hline (Constant) & 62.909 & 21.064 & & 2.987 & .004 & & \\
\hline Roa & -32.184 & 14.246 & -.245 & -2.259 & .026 & .841 & 1.190 \\
\hline Der & -5.568 & 3.152 & -.189 & -1.767 & .081 & .868 & 1.152 \\
\hline up & 1.235 & .759 & .169 & 1.628 & .107 & .922 & 1.084 \\
\hline opini & 4.470 & 3.072 & .150 & 1.455 & .149 & .937 & 1.067 \\
\hline
\end{tabular}

a. Dependent Variable: time

\section{Uji Multikolinearitas}

Berdasarkan uji multikolinearitas yang telah dilakukan sesuai dengan yang ditunjukkan dalam tabel diatas, diperoleh hasil bahwa semua nilai tolerance variabel independen yang 
ada $\geq 0,1$ dan semua nilai variance Inflation Factor (VIF) yang ada $\leq 10$ sehingga dapat disimpulkan tidak terjadi multikolinearitas (korelasi

\section{Analisis Regresi Berganda}

antar variabel bebas) dalam model regresi pengujian. (Lihat tabel $7 \mathrm{Uji}$ Multikolinearitas).

Tabel 8. Hasil Uji Analisis Regresi Berganda

\begin{tabular}{|c|c|c|c|c|c|c|c|}
\hline \multirow[t]{2}{*}{ Model } & \multicolumn{2}{|c|}{$\begin{array}{l}\text { Unstandardized } \\
\text { Coefficients }\end{array}$} & \multirow{2}{*}{$\begin{array}{c}\text { Standardized } \\
\text { Coefficients } \\
\text { Beta }\end{array}$} & \multirow[t]{2}{*}{$\mathrm{t}$} & \multirow[t]{2}{*}{ Sig. } & \multicolumn{2}{|c|}{$\begin{array}{c}\text { Collinearity } \\
\text { Statistics }\end{array}$} \\
\hline & B & $\begin{array}{l}\text { Std. } \\
\text { Error }\end{array}$ & & & & Tolerance & VIF \\
\hline (Constant) & 62.909 & 21.064 & & 2.987 & .004 & & \\
\hline roa & -32.184 & 14.246 & -.245 & -2.259 & .026 & .841 & 1.190 \\
\hline der & -5.568 & 3.152 & -.189 & -1.767 & .081 & .868 & 1.152 \\
\hline up & 1.235 & .759 & .169 & 1.628 & .107 & .922 & 1.084 \\
\hline opini & 4.470 & 3.072 & .150 & 1.455 & .149 & .937 & 1.067 \\
\hline
\end{tabular}

a. Dependent Variable: time

Hasil Analisis Regresi Linear

\section{Berganda}

Berdasarkan hasil penelitian analisis linear berganda yang telah dilakukan dengan menggunakan program Statistical Package for Social Science (SPSS) 20, maka diperoleh persamaan regresi sebagai berikut:

$$
\text { TIME }=62,909-32,184 \text { X1 - 5,568 X2 + 1,235 X3 + 4,470 X4 }
$$

\section{Pengujian Hipotesis}

\section{Uji F}

Tabel 9. Hasil Uji F (ANOVA)

\begin{tabular}{|c|c|c|c|c|c|}
\hline Model & $\begin{array}{l}\text { Sum of } \\
\text { Squares }\end{array}$ & Df & Mean Square & $\mathrm{F}$ & Sig. \\
\hline Regression & 1487.973 & 4 & 371.993 & 2.480 & $.049^{\mathrm{b}}$ \\
\hline Residual & 13650.266 & 91 & 150.003 & & \\
\hline Total & 15138.240 & 95 & & & \\
\hline
\end{tabular}

a. Dependent Variable: time

b. Predictors: (Constant), opini, up, der, roa 
Berdasarkan uji stastistik F hasil sig menunjukkan $.049<0,05$ berarti semua variabel profitabilitas, solvabilitas, ukuran perusahaan dan opini audit memiliki pengaruh terhadap ketepatan waktu penyampaian laporan keuangan perusahaan. (Lihat tabel 9 Hasil Uji F).

\section{Uji t}

Tabel 10. Hasil Uji t

\begin{tabular}{|c|c|c|c|c|c|}
\hline \multirow[t]{2}{*}{ Model } & \multicolumn{2}{|c|}{$\begin{array}{l}\text { Unstandardized } \\
\text { Coefficients }\end{array}$} & \multirow{2}{*}{$\begin{array}{c}\text { Standardized } \\
\text { Coefficients } \\
\text { Beta } \\
\end{array}$} & \multirow[t]{2}{*}{$\mathrm{t}$} & \multirow[t]{2}{*}{ Sig. } \\
\hline & $\mathrm{B}$ & Std. Error & & & \\
\hline (Constant) & 62.909 & 21.064 & & 2.987 & .004 \\
\hline Roa & -32.184 & 14.246 & -.245 & -2.259 & .026 \\
\hline Der & -5.568 & 3.152 & -.189 & -1.767 & .081 \\
\hline Up & 1.235 & .759 & .169 & 1.628 & .107 \\
\hline Opini & 4.470 & 3.072 & .150 & 1.455 & .149 \\
\hline
\end{tabular}

a. Dependent Variable: time

Berdasarkan uji t, maka dapat dilihat pengaruh antara variabel independen terhadap variabel dependen secara parsial adalah sebagai berikut :

(1) Variabel ROA memiliki nilai signifikansi (sig.t) $0,026 / 2=$ 0,013 dan nilai koefisien betanya bertanda negatif. Ini membuktikan bahwa ROA (Return on Asset) berpengaruh negatif terhadap timeliness karena nilai sig.t variabel ROA $0,013<0,05$, sehingga hipotesis 1 yang menyebutkan bahwa ROA berpengaruh negatif terhadap timeliness dapat diterima.
(2) Variabel DER memiliki nilai signifikansi (sig.t) $0,081 / 2=$ 0,0405 dan nilai koefisien betanya bertanda negatif. Ini membuktikan bahwa DER (Debt to Equity Ratio) berpengaruh negatif terhadap timeliness karena nilai sig.t variabel DER $0,0405<0,05, \quad$ sehingga hipotesis 2 yang menyebutkan bahwa DER berpengaruh positif terhadap timeliness dapat ditolak.

(3) Variabel ukuran perusahaan memiliki nilai signifikansi (sig.t) $0,107 / 2=0,0535$ dan koefisien beta-nya bertanda positif. Ini 
membuktikan bahwa ukuran perusahaan tidak berpengaruh terhadap timeliness karena nilai sig.t variabel ukuran perusahaan $0,0535>0,05, \quad$ sehingga hipotesis 3 yang menyebutkan bahwa ukuran perusahaan berpengaruh positif terhadap timeliness tidak dapat diterima.

(4) Variabel opini audit memiliki nilai signifikansi (sig.t) $0,149 / 2$
$=0,0745$ dan nilai koefisien beta-nya bertanda positif. Ini membuktikan bahwa opini audit berpengaruh positif terhadap timeliness karena nilai sig.t variabel opini audit 0,0745> 0,05 , sehingga hipotesis 4 yang menyebutkan bahwa opini audit berpengaruh negatif terhadap timeliness tidak dapat diterima. (Lihat tabel $10 \mathrm{Uji} \mathrm{t}$ ).

\section{Uji Koefisien Determinasi}

Tabel 11. Hasil Model Summary

\begin{tabular}{rrrrr}
\hline Model & R & R Square & Adjusted R Square & $\begin{array}{c}\text { Std. Error of the } \\
\text { Estimate }\end{array}$ \\
\hline $.314^{\mathrm{a}}$ & .098 & .059 & 12.24757 \\
\hline
\end{tabular}

a. Predictors: (Constant), opini, up, der, roa

Berdasarkan hasil uji koefisien determinasi diperoleh hasil $\mathrm{R}^{2}$ sebesar 0,059 (5,9\%) yang artinya variabel ketepatan waktu dapat dijelaskan sebesar 5,9\% oleh variabel profitabilitas, solvabilitas, ukuran

\section{Pembahasan}

\section{Pengaruh Ukuran Perusahaan} terhadap Ketepatan Waktu

Dari uji statistik $\mathrm{t}$ yang telah dilakukan terlihat bahwa ROA berpengaruh terhadap timeliness dari taraf signifikansi variabel ROA sebesar 0,013 yang lebih perusahaan dan opini audit. Sedangkan 94,1\% dijelaskan oleh variabel lain yang tidak digunakan dalam model penelitian ini. (Lihat tabel 11 Uji Koefisien Determinasi).

kecil dari 0,05 dengan nilai $\beta$ sebesar -32,184 yang berarti pengaruh ROA terhadap timeliness merupakan pengaruh negatif. Berdasarkan hasil pengujian tersebut dapat disimpulkan bahwa variabel ROA berpengaruh negatif 
terhadap timeliness, sehingga hipotesis 1 diterima.

Adanya pengaruh negatif ini mempunyai arah yang sama dengan hipotesis 1 dan sesuai dengan hasil penelitian yang telah dilakukan oleh Hilmi dan Ali (2008) dan Toding dan Wirakusuma (2013), dimana koefisien yang negatif menunjukkan bahwa perusahaan yang memiliki tingkat profitabilitas yang tinggi cenderung akan mempublikasikan laporan keuangan tahunan perusahaan secara tepat waktu untuk mengumumkan good news kepada publik. Hasil penelitian ini mendukung teori sinyal yang menyatakan bahwa perilaku manajemen dalam mengkomunikasikan suatu informasi tentang perusahaan dimana jika perusahaan yang menyampaikan laporan keuangan secara tepat waktu dapat dikatakan perusahaan tersebut memiliki good news, perusahaan yang memiliki good news cenderung ingin segera menyampaikan kabar baik tersebut kepada publik sehingga harga saham diharapkan meningkat. Sebaliknya jika perusahaan yang menyampaikan laporan keuangannya terlambat dapat dikatakan bahwa perusahaan tersebut memiliki bad news, dimana perusahaan tersebut berusaha menutupi kabar buruk tersebut kepada publik.

Namun hasil penelitian ini tidak sejalan dengan penelitian Rachmawati (2008), Yusralaini (2010) dan Kadir (2011) yang menyatakan bahwa profitabilitas perusahaan tidak berpengaruh terhadap timeliness.

\section{Pengaruh Reputasi KAP terhadap Ketepatan Waktu}

Dari uji statistik $\mathrm{t}$ yang telah dilakukan terlihat bahwa DER berpengaruh terhadap timeliness dari taraf signifikansi variabel DER sebesar 0,0405 yang lebih kecil dari 0,05 dengan nilai $\beta$ sebesar $-5,568$ yang berarti pengaruh DER terhadap timeliness merupakan pengaruh negatif. Berdasarkan hasil pengujian dapat disimpulkan 
bahwa DER berpengaruh negatif terhadap timeliness, sehingga hipotesis 2 ditolak.

Adanya pengaruh negatif ini mempunyai arah yang berbeda dengan hipotesis 2 dan sesuai dengan hasil penelitian Merdekawati (2011) dan Dewi dan Jusia (2013) yang menyatakan bahwa solvabilitas (DER) berpengaruh negatif terhadap timeliness. Hasil penelitian ini mendukung teori agensi yang menyatakan bahwa peningkatan biaya monitoring pada perusahaan yang memiliki tingkat hutang tinggi, karena adanya insentif dari kreditor dalam membatasi aktivitas manajemen (Jensen \& Meckling, 1976). Dalam pembiayaan operasional perusahaan, tentunya tidak terlepas dari adanya pinjaman dari pihak eksternal. Pinjaman tersebut dapat berupa hutang jangka panjang dan jangka pendek. Perusahaan yang memiliki tingkat hutang yang tinggi tidak hanya diartikan sebagai perusahaan yang memiliki risiko keuangan yang tinggi, melainkan perusahaan tersebut juga memiliki kepercayaan yang tinggi dari pihak kreditor dikarenakan kreditor berani untuk memberikan dana pinjaman yang besar kepada perusahaan tersebut. Tentunya pihak kreditor sudah menganalisa tingkat laba yang dapat dihasilkan perusahaan dengan pinjaman yang diberikan kepada perusahaan tersebut. Dengan pinjaman yang besar maka perusahaan juga dapat menghasilkan laba operasi yang lebih besar. Hal tersebut membuat perusahaan yang memiliki tingkat pinjaman yang tinggi tetap melaporkan laporan keuangannya secara tepat waktu. Konsekuensinya, perusahaan yang memiliki tingkat hutang yang tinggi akan mendapatkan tekanan dari kreditor untuk mempublikasi laporan keuangan yang tepat waktu.

Hasil penelitian ini tidak sejalan dengan penelitian yang dilakukan Hilmi dan Ali (2008), Wiratmo (2013), Toding dan Wirakusuma (2013) dan Mareta 
(2015) yang menyatakan bahwa leverage yang diproksikan dengan DER ini tidak berpengaruh terhadap

timeliness.

\section{Pengaruh Return on Asset} terhadap Ketepatan Waktu

Dari uji statistik $\mathrm{t}$ yang telah dilakukan terlihat bahwa taraf signifikansi variabel ukuran perusahaan sebesar 0,0535 yang lebih besar dari 0,05 dengan nilai $\beta$ sebesar 1,235 yang berarti pengaruh ukuran perusahaan terhadap timeliness merupakan pengaruh positif. Berdasarkan hasil penelitian dapat disimpulkan bahwa ukuran perusahaan tidak berpengaruh terhadap timeliness, sehingga hipotesis 3 ditolak. Hasil penelitian ini sejalan dengan penelitian yang dilakukan Dewi dan Jusia (2013), Mareta (2015) dan Hilmi dan Ali (2008). Hubungan yang tidak signifikan terjadi karena aset perusahaan meliputi piutang dan persediaan, dimana perusahaan yang memiliki piutang yang tinggi memiliki resiko yang tinggi dan perusahaan yang memiliki persediaan yang tinggi juga memiliki resiko yang tinggi dimana adanya resiko persediaan tidak habis terjual. Kedua hal tersebut merupakan alasan bahwa perusahaan dengan aset yang besar tidak selalu tepat waktu dalam mempublikasi laporan keuangan. Hal ini di lakukan perusahaan untuk menutupi kegagalan manager dalam menjalankan perusahaan. Sebaliknya, perusahaan yang memiliki liabilitas yang tinggi dalam mendanai asetnya akan mempublikasi laporan keuangan tepat waktu dikarenakan adanya pengawasan dari kreditor dalam membatasi perilaku manajer. Hasil penelitian ini tidak sejalan dengan Toding dan Wirakusuma (2014) serta Merdekawati (2012) yang menyatakan bahwa semakin besar ukuran perusahaan diharapkan dapat memiliki kemampuan yang lebih cepat dalam menyampaikan laporan keuangan, karena perusahaan 
yang besar tentu memiliki sumber daya lebih banyak, terutama staf keuangan atau akuntansi dengan didukung oleh teknologi yang canggih dan sistem pengendalian intern yang cukup kuat. Ukuran perusahaan juga menunjukkan jumlah pengalaman dan kemampuan tumbuhnya suatu perusahaan yang mengindikasikan kemampuan dan tingkat risiko dalam mengelola investasi yang diberikan para stockholder untuk meningkatkan kemakmuran mereka.

\section{Pengaruh Debt to Equity} Ratio terhadap Ketepatan Waktu

Dari uji statistik $\mathrm{t}$ yang telah dilakukan terlihat bahwa taraf signifikansi variabel opini audit sebesar 0,0745 yang lebih besar dari 0,05 dengan nilai $\beta$ sebesar 4,470 yang berarti pengaruh ukuran perusahaan terhadap timeliness merupakan pengaruh positif. Berdasarkan hasil penelitian dapat disimpulkan bahwa opini audit tidak berpengaruh terhadap timeliness, sehingga hipotesis 4 ditolak.

Hasil penelitian ini sejalan dengan penelitian yang dilakukan oleh Dewi dan Jusia (2013) yang menyatakan bahwa opini audit tidak berpengaruh signifikan terhadap timeliness. Hal ini dapat terjadi karena opini audit atas laporan keuangan yang disusun oleh auditor merupakan wewenang dari kantor akuntan publik sebagai lembaga yang independen dan bertanggungjawab ke publik untuk mengeluarkan opini berdasarkan laporan keuangan yang diauditnya. Dalam hal ini manajemen tidak berhak mengintervensi opini auditor yang telah dikeluarkan oleh kantor akuntan publik meskipun kantor akuntan publik tersebut mendapat fee dari perushaan yang diauditnya.

Selain itu, perusahaan yang mendapatkan opini selai wajar tanpa pengecualian dapat menyampaikan laporan keuangannya tepat waktu karena adanya aturan dalam lampiran 
Bapepam no X.2 yang menyebutkan bahwa perusahaan harus menyampaikan laporan keuangan beserta opini audit dari akuntan, maka opini audit tidak terjadi pertimbangan perusahaan dalam menyampaikan laporan keuangannya. Apabila perusahaan tidak ingin dikenai sanksi denda karena melanggar peraturan Bapepam, maka perusahaan wajib menyampaikan laporan keuangannya dengan tepat waktu.

Namun hasil penelitian ini tidak sejalan dengan penelitian yang dilakukan oleh Merdekawati (2011), Yusralaini (2010), serta Mareta (2015) yang menunjukkan bahwa opini audit berpengaruh secara signifikan terhadap timeliness.

\section{KESIMPULAN}

Berdasarkan pembahasan sebelumnya, Hasil penelitian ini menyimpulkan bahwa variabel Return on Assets memiliki pengaruh negatif terhadap timeliness. Debt to Equity Ratio terbukti memiliki pengaruh negatif terhadap timeliness sehingga hasilnya inkonklusif atau tidak relevan dengan hipotesis penelitian. Ukuran Perusahaan terbukti tidak memiliki pengaruh terhadap timeliness. Opini Audit terbukti tidak memiliki pengaruh terhadap timeliness.

Beberapa saran yang dapat diberikan bagi peneliti selanjutnya, diharapkan menggunakan sampel yang lebih besar dan menyangkut banyak sektor perusahaan seperti perusahaan jasa keuangan, sektor industri dan lain sebagainya yang terdaftar di Bursa Efek Indonesia. Penelitian ini hanya menggunakan data 4 tahun untuk menghitung timeliness. penelitian selanjutnya diharapkan dapat menggunakan rentang waktu yang lebih panjang untuk menghasilkan penelitian yang lebih akurat. Di dalam penelitian ini hanya menggunakan 4 variabel independen saja. Diharapkan penelitian selanjutnya dapat menambah variabel-variabel lain yang sekiranya dapat mempengaruhi timeliness, seperti reputasi KAP dan Kompleksitas operasi perusahaan. 


\section{DAFTAR PUSTAKA}

Asnawi, S. K., \& Wijaya, C. (2015), FINON (Finance for Non Finance) Manajemen Keuangan untuk Non Keuangan, Edisi Ke-1, Depok: PT Rajagrafindo Persada.

Chambers, Anne E. \& Stephen H. Penman. (1984), Timeliness of Reporting and the Stock Price Reaction to Earnings Announcements, Journal of Accounting Research, 1984 Vol. 22, No. 1.

Dewi, I. G. A. R. P. dan Wirakusuma, M. G. (2014), Fenomena Ketepatwaktuan Informasi Keuangan Dan Faktor yang Mempengaruhi Di Bursa Efek Indonesia, Jurnal Akuntansi Universitas Udayana 8.1, 171-186

Dewi, S. P., \& Jusia. (2013), Faktorfaktor yang Mempengaruhi Ketepatan Waktu Penyampaian Laporan Keuangan Pada Perusahaan Real Estate dan Property yang Terdaftar di BEI. Jurnal Akuntansi, Vol. 17, No. 03, September 2013 , 368-384.

Diaz, Rafika dan Jufrizen (2014), Pengaruh Retun on Assets (ROA) dan Return on Equity (ROE) Terhadap Earning Per Share (EPS) Pada Perusahaan Asuransi yang Terdaftar di Bursa Efek Indonesia, Jurnal Manajemen dan Bisnis Vol. 14, No. 02.
Dyer, J. C., \& McHugh, A. J. (1975), The Timeliness oh the Australian Annual Report, Journal of Accounting Research, Vol. 13, No. 2 , 204-219.

Ghozali, I. (2016), Aplikasi Analisis Multivariete Dengan Program IBM SPSS 23, Semarang: Badan Penerbit Universitas Diponegoro.

Hilmi, U., \& Ali, S. (2008), Analisis Faktor-faktor yang Mempengaruhi Ketepatan Waktu Penyampaian Laporan Keuangan, Simposium Nasional Akuntansi IX Ikatan Akuntan Indonesia, 1-26.

Indonesia, I. A. (2015), Standar Akuntansi Keuangan, Jakarta: Ikatan Akuntan Indonesia.

Institut Akuntan Publik Indonesia. (2011), Standar Profesional Akuntan Publik. Jakarta: Salemba Empat.

Jaswadi. (2004), Dampak Earnings Reporting Lags terhadap Koefisien Respon Laba, Jurnal Riset Akuntansi Indonesia, Vol 7. No. 3 , 295315.

Jensen, M. C., \& Meckling, W. H. (1976), Theory of The Firm: Managerial Behavior, Agency Costs and Ownership Structure, Journal of Financial Economics 3 , 305360. 
Kadir, A. (2011), Faktor-faktor yang Berpengaruh Terhadap Audit Delay Pada Perusahaan Consumer Goods yang Terdaftar di Bursa Efek Indonesia, Jurnal Akuntansi dan Manajemen, Vol. 12, No. $1,1-12$.

Kasmir. (2015), Analisis Laporan Keuangan, Edisi ke-7, Jakarta: PT Raja Grafindo Persada.

Mareta, S. (2015), Analisis Faktorfaktor yang Memengaruhi Timeliness Publikasi Laporan Keuangan Periode 20092010, Jurnal Akuntansi, Vol. 19, No. 01, Januari 2015 , 93108.

Merdekawati, I., \& Arsjah, R. J. (2011), Timeliness of Financial Reporting Analysis: An Empirical Study In Indonesia Stock Exchange, Simposium Nasional Akuntansi XIV, Aceh 2011 , $1-31$.

Oktomegah, C. (2012), Faktor-faktor yang Mempengaruhi Penerapan Konservatisme Pada Perusahaan Manufakturdi BEI, Jurnal Ilmiah Mahasiswa Akuntansi, Vol 1, No. 1 , 36-42.

Rachmawati, S. (2008), Pengaruh Faktor Internal dan Eksternal Perusahaan Terhadap Audit Delay dan Timeliness, Jurnal Akuntansi dan Keuangan, Vol. 10, No. 1, Mei 2008 , 110.
Scott, W. R. (2015), Financial Accouting Theory, 7th Edition, Canada: Pearson Canada Inc.

Sudarmadji, A. M., \& Sularto, L. (2007), Pengaruh Ukuran Perusahaan, Profitabilitas, Leverage, dan Tipe Kepemilikan Perusahaan Terhadap Luas Voluntary Disclosure Laporan Keuangan Tahunan, Auditorium Gunadarma, Vol.2, A53-A61.

Sugiono, A. (2009), Manajemen Keuangan untuk Praktisi Keuangan, Jakarta: PT Gramedia Widiasarana Indonesia.

Toding, M., \& Wirakusuma, M. G. (2013), Faktor-faktor yang Memengaruhi

Ketepatwaktuan

Penyampaian Laporan Keuangan, Jurnal Akuntansi Universitas Udayana 3.2 , 318-333.

Weygandt, J. J., Kieso, D. E., \& Warfield, T. D. (2015), Intermediate Accounting, Volume 1, IFRS Edition, United States: John Wiley and Sons.

Wiratmo, T., \& Sugiarto, B. (2013), Pengaruh Rasio Profitabilitas dan Solvabilitas Terhadap Ketepatan Waktu Pelaporan Keuangan Pada Industri Food and Beverages yang Terdaftar di Bursa Efek Indonesia Periode 20102012, Jurnal Akuntansi Manajemen, Vol. 2, No. 2 , 208-223. 
Wolk, Harry I., Michael G. Tearney \& James L. Dodd. (2001), A Conceptual and Institusional Approach Accounting Theory, Edisi 5, South Western College: Thomson.
Yusralaini, Gusti, R., \& Raesya, L. D. (2010), Analisis Faktorfaktor yang Mempengaruhi Ketepatan Waktu Penyampaian Laporan Keuangan ke Publik Pada Perusahaan yang Terdaftar di BEI (2005-2007), Jurnal Ekonomi, Vol. 18, No. 2 , 616. 